\title{
Effects of intrahippocampal administration of the phosphatase inhibitor okadaic acid Dual effects on memory formation
}

\author{
Monica R.M. Vianna ${ }^{1}$, Adriana Coitinho ${ }^{1}$, Luciana Izquierdo ${ }^{2}$, Ivan Izquierdo ${ }^{2}$
}

\begin{abstract}
Protein phosphorylation mediated by serine-threonine kinases in the hippocampus is crucial to the synaptic modifications believed to underlie memory formation. The role of phosphatases has been the focus of comparatively little study. Objectives: Here we evaluate the contribution of the serine-threonine protein phosphatases 1 and 2A (PP1, PP2A) on memory consolidation. Methods: We used immediate post-training bilateral hippocampal infusions of okadaic acid (OA, 0.01 and $10 \mathrm{pmol} /$ side), a potent inhibitor of PP1 and PP2A, and measured short- [3 h] and long-term memory [24 h] (STM, LTM) of step-down inhibitory avoidance. Results: At the lower dose, OA inhibited both STM and LTM whereas at the higher dose it instead enhanced LTM. Pretest infusion of these two doses of OA had no effect on retrieval. Conclusions: These two doses of OA are known to selectively inhibit PP1 and PP2A respectively. These findings point to the importance of these enzymes in memory formation and also suggest a deleterious influence of endogenous hippocampal PP2A on LTM formation. Key words: hippocampus, PP1, PP2A, okadaic acid, short-term memory, long-term memory.
\end{abstract}

\begin{abstract}
Efeitos da administração intra-hipocampal do inibidor de fosfatases ácido okadaico: efeito duplo sobre a formação de memória

Resumo - A fosforilação de proteínas mediada por serina-treonina quinases no hipocampo é crucial para as modificações sinápticas que se acredita sejam necessárias para a formação de memórias. O papel das fosfatases tem sido comparativamente pouco estudado. Objetivos: Aqui avaliamos a contribuição das fosfatases serinatreonina 1 e 2 (PP1, PP2A) sobre a consolidação da memória. Métodos: Usamos infusões imediatamente após o treino de ácido okadaico (OA, 0.01 e 10 pmol/lado), um potente inibidor de PP1 e medimos memória de curta [3 h] e longa duração [24 h] (STM, LTM) de esquiva inibitória de evitar descer de uma plataforma. Resultados: Na dose menor, OA inibiu tanto STM como LTM. Na dose maior, produziu, em vez disso, uma melhora da LTM. A infusão pré-teste de qualquer uma das duas doses de OA não teve efeito sobre a evocação. Conclusões: Estas duas doses de OA são conhecidas por inibir seletivamente PP1 a PP2 respectivamente. Estes resultados apontam à importância das duas enzimas na formação de memória e sugerem, adicionalmente, uma influência deletérea da PP2A endógena sobre a formação de LTM.
\end{abstract}

Palavras-chave: hipocampo, PP1, PP2A, ácido ocadaico, memória de curto prazo, memória de longo prazo.

Several serine-threonine protein kinases constitute signaling pathways whose activation is necessary for memory formation in the hippocampus. ${ }^{1,2}$ These include the calcium-calmodulin dependent kinase [CaMKII] that mediates GluR1 phosphorylation, ${ }^{3,4}$ the cAMP-dependent [PKA] and mitogen-activated kinases [MAPK] that mediate phos- phorylation of the transcription factor CREB and other substrates, ${ }^{5-7}$ and the calcium-dependent protein kinase family (PKC) that also mediates the phosphorylation of many substrates, including presynaptic proteins involved in glutamate release. ${ }^{8,9}$ There is abundant cross-talk among all these kinase families. ${ }^{7,10}$ Their importance in memory sug-

${ }^{1}$ Faculty of Biosciences, National Institute of Translational Medicine and ${ }^{2}$ Memory Center, Brain Institute and National Institute of Translational Neuroscience, Pontifical Catholic University of Rio Grande do Sul, Porto Alegre RS, Brazil.

Ivan Izquierdo - Av. Ipiranga 6690 / 2º andar - 90610-000 Porto Alegre RS - Brazil. E-mail: ivan.izquierdo@pucrs.br

Disclosure: The authors report no conflicts of interest.

Received September 16, 2009. Accepted in final form February 20, 2010. 
gests that serine-threonine phosphatases such as PP1, PP2A and calcineurin may also play a role. ${ }^{11-14}$ Indeed, inhibitors of PP1 and PP2A enhance NMDA currents in cultured hippocampal neurons, ${ }^{15}$ but antagonize the NMDA receptordependent inhibition of late-long term potentiation (LTP) caused by low frequency stimulation in hippocampal slices. ${ }^{16}$ Both hippocampal early NMDA currents and late LTP appear to be necessary for memory formation. ${ }^{2,17,18}$ Inhibitors of PP1, PP2A and calcineurin have been shown to have deleterious effects on various forms of memory. ${ }^{11-}$ ${ }_{13,19-21}$ The best studied of these phosphatases is calcineurin, for which an allosteric model has been suggested in which, once bound to calmodulin, calcineurin competes with CaMKII for calcium. ${ }^{14}$ Calcineurin appears to govern both an intermediate phase of LTP between the so-called early and late phases, ${ }^{22}$ and the development of LTM for spatial and nonspatial tasks. ${ }^{23}$ The inducible and reversible genetic inhibition of calcineurin in mouse brain enhances learning, STM and LTM of hippocampus-dependent tasks and hippocampal LTP in a PKA-dependent manner. ${ }^{24}$

The influence of PP1 and PP2A on memory variables is less clear. Genetic inhibition of PP1 suppresses the deleterious effect of massed trials on learning, and prolongs memory duration. ${ }^{25}$ Suppression also decreases LTD and favors LTP in a frequency-dependent manner in the hippocampus. ${ }^{26}$ While these findings are important and point to a role of PP1 both in hippocampal plasticity and memory parameters, they are not illustrative, however, as to what specific phase of memory PP1 is involved in. No similar data are available for PP2A. Although some of the behavioral findings do suggest a different time course for the PP1 and PP2A influences on memory, ${ }^{21}$ it is not clear whether different forms of memory are affected by each. We have recently demonstrated a degree of independence of short-term memory lasting $3 \mathrm{~h}$ or less (STM) and longterm memory lasting one day or more (LTM), which are essentially parallel processes. ${ }^{27,28}$

Here we concentrate on the inhibition of hippocampal PP1 and PP2A by two widely differing dose concentrations of okadaic acid well known to selectively inhibit one or the other enzyme. ${ }^{21,29,30}$ We studied one-trial inhibitory avoidance in rats, a task equivalent to the one-trial peck avoidance task studied in the one-day-old chick by Bennett, $\mathrm{Ng}$ and their coworkers, ${ }^{11,12,19,21}$ which is also acquired in a few seconds and, in the rat, depends mainly on the hippocampus $^{2}$. In addition, it is the task in which STM and LTM were shown to be functionally separate ${ }^{27}$ and where LTM was found to use the same molecular cascades as LTP.,18

\section{Methods}

Adult 3 month-old Wistar male rats (250-300 g) pur- chased from Fundação Estadual de Produção e Pesquisa em Saúde do Rio Grande do Sul, Porto Alegre were used. The animals were housed 5 to a cage and had free access to food and water under a 12/12 h light/dark cycle, with lights on at 7:00 AM. The temperature of the animal room was maintained at $22-24^{\circ} \mathrm{C}$. To implant them with indwelling cannulae, rats were deeply anesthetized with thiopental (i.p., $30-50 \mathrm{mg} / \mathrm{kg}$ ) and 27 -gauge cannulae stereotaxically aimed at the CA1 region of the dorsal hippocampus, in accordance with coordinates ( $\mathrm{A} \pm 4.3, \mathrm{~L} \pm 3.0, \mathrm{~V} 3.4$ ) from the atlas of Paxinos and Watson. ${ }^{31}$ Animals were allowed to recover from surgery for 4 days before submitting them to any other procedure.

At the time of drug delivery, 30-gauge infusion cannulae were tightly fitted into the guides. Infusions $(0.5 \mu \mathrm{l} /$ side $)$ were carried out over a $60 \mathrm{~s}$ period and the cannulae were left in place for 60 additional seconds to minimize backflow. The placement of the cannulae was verified postmortem: 2-4 $\mathrm{h}$ after the last behavioral test, $0.8 \mu \mathrm{l}$ of a $4 \%$ methyleneblue solution was infused as described above and the spread of the dye 30 min thereafter was taken as an indication of the presumable diffusion of the vehicle or drug previously given to each animal. Only data from animals with correct cannulae implants were analyzed. All procedures were conducted in accordance with the 'Principles of laboratory animal care' (NIH publication No. 85-23, revised). After recovery from surgery, animals were trained in step-down inhibitory avoidance as described in detail elsewhere ${ }^{4,27}$ and immediately after training ${ }^{2-5,27}$ (Figure 1), or 5 min prior to testing $24 \mathrm{~h}$ later (Figure 2), they were infused bilaterally with $0.5 \mu$ of $0.01,1$ or 10 pmoles of OA (Calbiochem) or its vehicle (20\% dimetylsulfoxide). This lowest dose of OA is known to selectively inhibit PP1; intermediate doses do not affect the activity of any known phosphatase, while the highest dose of OA selectively inhibits PP2A. ${ }^{21,29,30}$ The infusion cannulae was fitted into the guide, its tip protruded $1 \mathrm{~mm}$ beyond that of the guide, and reached the CA1 region. Animals were tested for STM and LTM at $3 \mathrm{~h}$ and $24 \mathrm{~h}$ after training, respectively, ${ }^{27}$ and their latency to step-down from the platform onto the floor grid was measured automatically. Upon placing their four paws on the grid they received a $0.4 \mathrm{~mA}, 2 \mathrm{sec}$ scrambled footshock on the training session. No footshocks were delivered during the STM or LTM test sessions. ${ }^{3-5,27}$ As is customary, ${ }^{2-5,27,28}$ the posttraining infusions were used to study drug effects on STM and/or LTM consolidation, and the pre-test infusions were used to study drug effects on retrieval.

To identify any unspecific side effects of the treatments on locomotor or exploratory activity we examined the effect of the doses of okadaic acid that significantly influenced memory on performance in an open-field task. The 


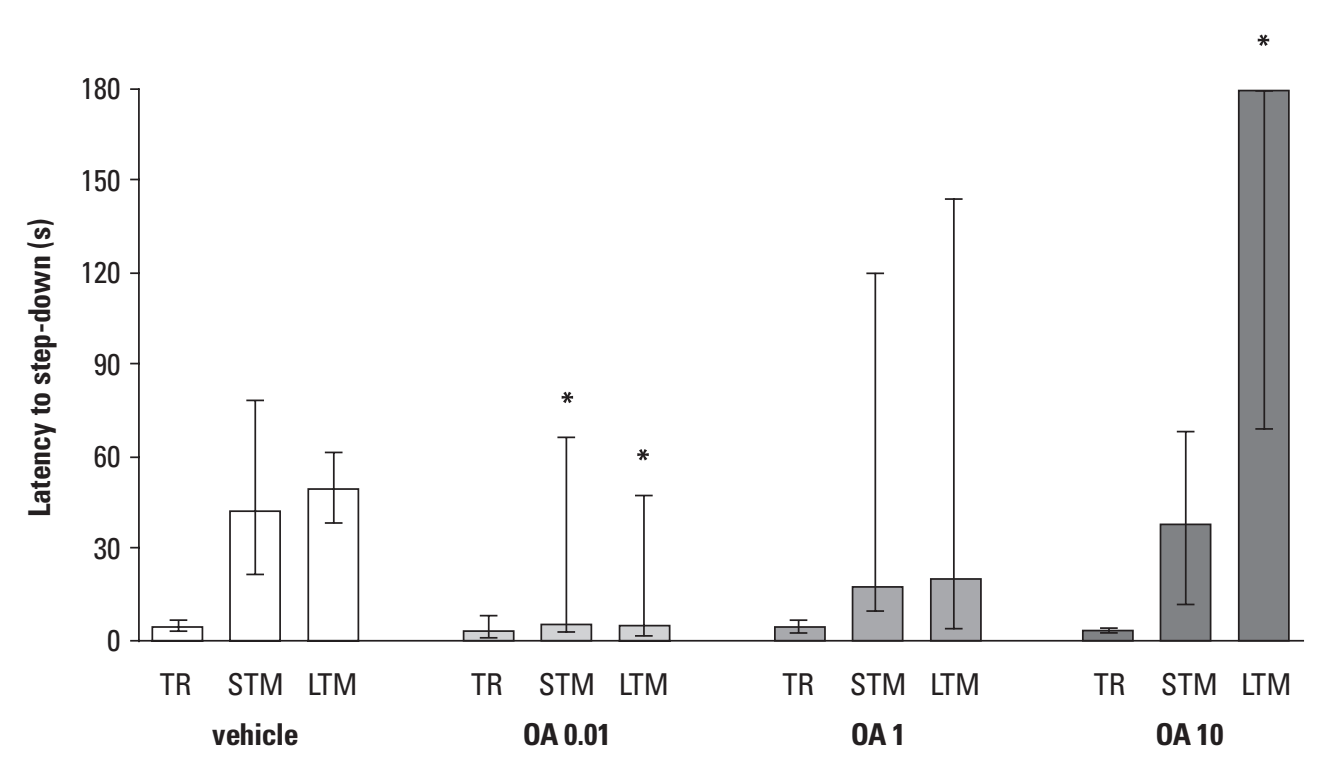

Figure 1. Effect of bilateral intrahippocampal infusions of $O A$ at different concentrations $(0.01,1$ and 10 $\mathrm{pmol} / \mathrm{side}$ ) immediately after step-down inhibitory avoidance training session. Control group received vehicle (20\% dimethylsulfoxide in saline) in which OA was diluted. Columns indicate Medians (interquartile ranges) of step-down latencies in seconds, of training (TR) and STM and LTM tests for each group. Asterisks indicate significant statistical difference at $p<0.05$ level on the Mann-Whitney $U$ test, to the respective control groups in the respective session.

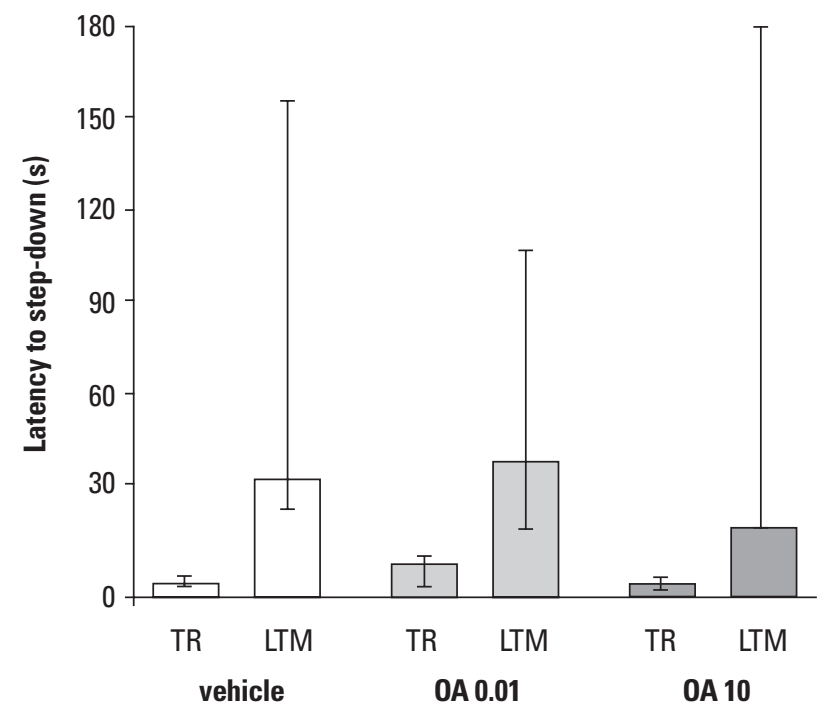

Figure 2. Effect of bilateral intrahippocampal infusions of $O A$ on memory retrieval when given $15 \mathrm{~min}$ before test session. Control group received vehicle (20\% dimethylsulfoxide in saline) in which Okadaic acid was diluted. Treated animals received Okadaic at 1 and $10 \mathrm{pmol} / \mathrm{side}$. Columns indicate medians, and vertical lines indicate interquartile ranges of step-down latencies in seconds, of training (TR) and LTM test for each group. Asterisks indicate significant statistical difference at least at $p<0.05$ level on the Mann-Whitney $U$ test, to the respective control groups in the respective session. animals' capacity of habituation to the novel environment (a $50 \mathrm{~cm}$ high, $50 \mathrm{~cm}$ wide and $39 \mathrm{~cm}$ deep open-field made of plywood painted white), and their locomotion and rearing was measured during a 5-min session. Locomotion was evaluated by counting crossings of black lines drawn on the floor of the cbox that divided it into 12 equal rectangles. In order to detect habituation performance of crossings and rearings in the first half of the session $(2.5 \mathrm{~min})$, these were compared to performances during the second half of the session. ${ }^{33}$ Habituation was measured as a significant decrease in both responses during the two halves of the session.

Only behavioral data from animals with correct cannulae placement was included in the final statistical analysis (Kruskal Wallis test followed by Mann Whitney for comparison among groups), as confirmed by histological control of cannulae placement.

\section{Results}

As shown in Figure 1, the intrahippocampal administration of 0.01 pmol of okadaic acid per side caused full amnesia for both STM and LTM on the inhibitory avoidance task. The 1 pmol dose was not effective and, surprisingly, the $10 \mathrm{pmol} /$ side dose had a positive effect on LTM retention.

In addition, as shown in Figure 2, the two doses of okadaic acid that affected consolidation of the avoidance task 
Table 1. Effect of intrahippocampal infusion of okadaic acid at doses that efficiently affected inhibitory avoidance memory ( 0.01 and 10 $\mathrm{pmol} / \mathrm{side}$ ) on crossings and rearings in the open field. Animals received bilateral infusions of vehicle (20\% dimethylsulfoxide in saline) or okadaic acid into the hippocampus bilaterally 15 minutes prior to being placed in the open field. Data are shown as means \pm standard deviations of total responses in the 5 min session, followed by the number of responses in the first and in the second half of the session.

\begin{tabular}{|c|c|c|c|c|c|c|}
\hline \multirow[b]{2}{*}{ Group } & \multicolumn{3}{|c|}{ Rearing responses } & \multicolumn{3}{|c|}{ Crossings } \\
\hline & $\begin{array}{c}\text { Total } \\
\text { rearings }\end{array}$ & $\begin{array}{l}\text { Rearings } \\
0-2.5 \mathrm{~min}\end{array}$ & $\begin{array}{l}\text { Rearings } \\
2.5-5 \mathrm{~min}\end{array}$ & $\begin{array}{c}\text { Total } \\
\text { crossings }\end{array}$ & $\begin{array}{l}\text { Crossings } \\
0-2.5 \text { min }\end{array}$ & $\begin{array}{l}\text { Crossings } \\
2.5-5 \text { min }\end{array}$ \\
\hline Vehicle & $8.1 \pm 3.5$ & $6.0 \pm 2.0$ & $2.1 \pm 1.7^{\mathrm{a}}$ & $48.1 \pm 31.0$ & $25.3 \pm 9.6$ & $12.8 \pm 8.6^{a}$ \\
\hline OA $0.01 \mathrm{pmol} / \mathrm{side}$ & $12.0 \pm 8.5$ & $8.3 \pm 6.2$ & $3.7 \pm 3.1^{\mathrm{a}}$ & $55.8 \pm 22.9$ & $32.6 \pm 14.6$ & $23.2 \pm 13.6^{\mathrm{a}}$ \\
\hline OA $10.0 \mathrm{pmol} / \mathrm{side}$ & $9.5 \pm 6.9$ & $6.5 \pm 4.3$ & $3.1 \pm 3.5^{\mathrm{a}}$ & $47.3 \pm 22.1$ & $34.3 \pm 18.4$ & $13.0 \pm 11.4^{\mathrm{a}}$ \\
\hline
\end{tabular}

aindicates significant difference between the two halves of the session at $\mathrm{p}<0.05$ level on a post-hoc Duncan test. There was habituation of both crossings and rearings at each $2.5 \mathrm{~min}$ block (0-2.5 $\mathrm{min}$ and 2.5-5 $\mathrm{min})$ for each group tested. No significant difference was found among all groups, and okadaic acid had no effect on this relationship.

had no effect on retrieval when given 5 min prior to the STM or the LTM test.

Table 1 illustrates that none of the treatments affected locomotion or exploration or their habituation in a $5 \mathrm{~min}$ open field session.

\section{Discussion}

The amnestic effect of OA on both STM and LTM corroborate previous findings of acute and chronic treatments with OA involving various tasks and species..$^{12,19,21,33}$ At a dose known to selectively inhibit PP1 $(0.01 \mathrm{pmol} /$ side), ${ }^{21,29,30}$ post-training intrahippocampal OA depressed both STM and LTM. At a dose known to selectively inhibit PP2A but not PP1 (10 pmol/side), ${ }^{21,29,30}$ post-training hippocampal OA specifically enhanced LTM consolidation. ${ }^{2,28}$ At an intermediate dose $(1 \mathrm{pmol})$ which does not inhibit either enzyme, ${ }^{29,30} \mathrm{OA}$ had no effect on either of the two forms of memory. Whether administered at the lower or at the higher dose, intrahippocampal OA given prior to retention testing had no effect on retrieval.

PP1 and PP2A interact with, and modulate, several intracellular signaling pathways known to influence LTD, LTP and LTM consolidation. ${ }^{13-16,22,23}$ The present findings provide no clues as to what specific system(s) participate in the amnesic influence of $\mathrm{OA}$ at the lower dose, or the mechanisms underlying the enhancing effect on LTM at the highest dose. Nevertheless, the latter phenomenon clearly points to an inhibitory role of endogenous PP2A in LTM consolidation.

Phosphatases, in particular calcineurin and $\mathrm{PP} 1,{ }^{25}$ have been suggested to act as inhibitory constraints to memory formation ${ }^{25}$ and, alternatively, to represent mechanisms of active forgetting. ${ }^{34}$ Although the evidence available does not allow us to determine which is the most accurate of these descriptions, both hypotheses reinforce the wellknown complexity of the cognitive processes and point to phosphatases as important factors. The importance of a degree of forgetting ${ }^{34,35}$ in order to establish new or important memories has been recently studied in detail, ${ }^{35}$ including its implications in terms of catabolic biochemical processes. ${ }^{36}$ It is possible that the enhancement of LTM formation by $\mathrm{OA}$, at the dose that inhibits PP2A, may be related to this forgetting activity.

\section{References}

1. Winder DG, Sweatt JD Roles of serine/threonine phosphatases in hippocampal synaptic plasticity. Nature Rev Neurosci 2001; 2:461-474.

2. Izquierdo I, Bevilaqua LRM, Rossato JI, Bonini JS, Medina JH, Cammarota M. Different molecular cascades in different sites of the brain control consolidation. Trends Neurosci 2006;29: 496-505.

3. Cammarota M, Bernabeu R, Levi de Stein M, Izquierdo I, Medina JH. Learning-specific, time-dependent increases in hippocampal Ca2+/calmodulin-dependent protein kinase II activity and AMPA GluR1 subunit immunoreactivity. Eur J Neurosci 1998;10:2669-2676.

4. Bevilaqua LR, Medina JH, Cammarota M, Izquierdo I. Memory consolidation induces $\mathrm{N}$-methyl-d-aspartic acid receptor and $\mathrm{Ca}(2+) /$ calmodulin-dependent protein kinase II-dependent modifications in alpha-amino-3-hydroxy-5methylisoxazole-4-propionic acid receptor properties. Neurosci 2005;136: 397-403.

5. Bernabeu R, Bevilaqua L, Ardenghi P, Bromberg E, Schmitz $\mathrm{P}$, Bianchin M, Izquierdo I, Medina JH. Involvement of hippocampal D1/D5 receptor - cAMP signaling pathways in a late memory consolidation phase of an aversively-motivated task in rats. Proc Natl Acad Sci USA 1997;94:7041-7046.

6. Samuels IS, Karlo JC, Faruzzi AN, et al. Deletion of ERK2 mitogen-activated protein kinase identifies its key roles in cortical neurogenesis and cognitive function. J Neurosci 2008; 28:6983-6995.

7. Schrader LA, Ren Y, Cheng F, Bui D, Sweatt JD, Anderson AE. Kv4.2 is a locus for PKC and ERK/MAPK cross-talk. Biochem J 2009;417:705-715. 
8. Paratcha G, Furman M, Bevilaqua L, et al. Involvement of hippocampal PKC $\beta I$ isoform in the early phase of memory formation of an inhibitory avoidance learning. Brain Res 2000;855:199-205.

9. Holahan M, Routtenberg A. The protein kinase C phosphorylation site on GAP-43 differentially regulates information storage. Hippocampus 2008;18:1099-1102.

10. Riedel G, Platt B. From messengers to molecules. New York: Kluwer Academic; 2004: 614.

11. Zhao W, Bennett P, Sedman GL, Ng KT. The impairment of long-term memory formation by the phosphatase inhibitor okadaic acid. Brain Res Bull 1995;36:557-561.

12. Bennett PC, Moutsoulas P, Lawen A, Perini E, Ng KT. Novel effects on memory observed following unilateral intracranial administration of okadaic acid, cyclosporine A, FK506 and [VeVal4]CyA. Brain Res 2003;988:56-68.

13. Mansuy IM, Shenolikar S. Protein serine/threonine phosphatases in neuronal plasticity and disorders of learning and memory. Trends Neurosci 2006;29:679-686.

14. Stefan MI, Edelstein SJ, Le Novère N. An allosteric model of calmodulin explains differential activation of PP2B and CaMKII. Proc Natl Acad Sci USA 2008;105:10768-10773.

15. Wang LY, Orser BA, Brautigan DL, MacDonald JF. Regulation of NMDA receptors in cultured hippocampal neurons by protein phosphatases 1 and 2A. Nature 1994;369:230-232.

16. Woo NH, Nguyen PV. Silent metaplasticity of the late phase of long-term potentiation requires protein phosphatases. Learn Mem 2002;9:202-213.

17. Gruart A, Muñoz MD, Delgado-García JM. Involvement of the CA3-CA1 synapse in the acquisition of associative learning in behaving mice. J Neurosci 2006;26:1077-1087.

18. Whitlock JR, Heynen AJ, Shuler MG, Bear MF. Learning induces long-term potentiation in the hippocampus. Science 2006;313:1093-1097.

19. Bennett PC, Zhao W, Lawan A, Ng KT. Cyclosporin A, an inhibitor of calcineurin, impairs memory formation in dayold chicks. Brain Res 1996;730:107-117.

20. Sun L, Liu SY, Zhow XW, Wang XC, Liu R, Wang Q, Wang JZ. Inhibition of protein phosphatase $2 \mathrm{~A}$ - and protein phosphatase 1-induced tau hyperphosphorylation and impairment of spatial memory retention in rats. Neurosci 2003;118:1175-1182.

21. Bennett PC, Zhao W, Ng KT. Concentration-dependent effects of protein phosphatases (PP) inhibitors implicate PP1 and PP2A in different stages of memory formation. Neurobiol Learn Mem 2001;75:91-110. 22.
22. Winder DG, Mansuy IM, Osman M, Moallem TM, Kandel ER. Genetic and pharmacological evidence for a novel, intermediate phase of long-term potentiation suppressed by calcineurin. Cell 1998;92:25-37.

23. Mansuy IM, Mayford M, Jacob B, Kandel ER, Bach ME. Restricted and regulated overexpression reveals calcineurin as a key component in the transition from short-term to longterm memory. Cell 1998;92:39.

24. Malleret G, Haditsch U, Genoux D, et al. Inducible and reversible enhancement of learning, memory, and long-term potentiation by genetic inhibition of Calcineurin. Cell 2001; 104:675-686.

25. Genoux D, Haditsch U, Knobloch M, Michalon A, Storm D, Mansuy IM. Protein phosphatase 1 is a molecular constraint on learning and memory. Nature 2002;418:929-930.

26. Jouvenceau A, Hédou G, Potier B, Kollen M, Dutar P, Mansuy IM. Partial inhibition of PP1 alters bidirectional synaptic plasticity in the hippocampus. Eur J Neurosci 2006;24:564-572.

27. Izquierdo I, Barros DM, Mello e Souza T, Souza MM, Izquierdo LA, Medina JH. Mechanisms for memory types differ. Nature 1998;393:635-636.

28. McGaugh JL. Memory: a century of consolidation. Science 2000;287:248-251.

29. Cohen P, Alemany S, Hemmings BA, Resink TJ, Strålfors P, Tung HY. Protein phosphatase-1 and protein phosphatase-2A from rabbit skeletal muscle. Meth Enzymol 1988;159:390-408.

30. Grahame-Hardie D. Protein phosphorylation: a practical approach, Oxford Academic Press: Oxford; 1999.

31. Paxinos G, Watson C. The Rat Brain in Stereotaxic Coordinates. Academic Press: San Diego; 1986.

32. Vianna MR, Alonso M, Viola H, et al. Role of hippocampal signaling pathways in long-term memory formation of a nonassociative learning task in the rat. Learn Mem 2000;7:333-340.

33. Arendt T, Holzer M, Fruth R, Bruckner MK, Gartner U. Paired helical filament-like phosphorylation of tau, deposition of beta/A4-amyloid and memory impairment in rat induced by chronic inhibition of phosphatase 1 and 2A. Neuroscience 1995;69:691-698.

34. Silva AJ, Josselyn SA. The molecules of forgetfulness. Nature 2002;418:929-930.

35. Izquierdo I. A arte de esquecer. Rio de Janeiro, Vieira \& Lent; 2004.

36. Lopez-Salon M, Alonso M, Vianna, MR, Viola H, Mello e Souza T, Izquierdo I, Pasquini JM, Medina JH. The ubiquitinproteasome cascade is required for mammalian long-term memory formation. Eur J Neurosci 2001;14:1820-1826. 